7）日本シリカ工業(㭌) カタログ

10）二宮：高分子，12，760(1963）

8）二宮，草水，甘滈，怡土：ゴム協 35，250

11）荒井：富分子化学，18，292(1961) $(.1962)$

12）草水他：未発表実験結果

9）前川，安田，二宮，怡土：ゴム協 36, 714

13）河合，小川：滈分子，12，752(1963) (1963)

14) J. H. Fielding: Ind. Eng. Chem., 29, 880(1937)

\title{
NON-LINEAR VISGOELASTIG PROPERTIES OF RUBBER-LIKE POLYMERS
}

\section{PART II. RELAXATION OF TENSILE STRESS IN PLASTIGIZED AND FILLEDPOLYMERS AT LARGE DEFORMATIONS}

G. Yasuda and K. Ninomiya (Research Laboratory, Japan Synthetic Rubber Co., Ltd.)

Tensile stress relaxation behavior at large deformations were further investigated for seventeen samples of raw, oil-extended and filler-loaded rubbers. The temperature range and the strain range tested were $35 \sim$ $135^{\circ} \mathrm{C}$ and $0.1 \sim 5.0$, respectively.

All of the samples were found to be thermorheologically simple irrespective of the magnitude of strain. Thus

$$
S(t)=S_{0}\left(t / a_{T}\right)
$$

where $S(t)$ and $S_{0}(t)$ are the relaxation stress (true) at an arbitrarily chosen and a reference temperatures, respectively, and $a_{x}$, shift factor, appeared to be little affected by the change in strain.

Time dependences of relaxation stress, $S(t)$, in all samples were found to be expressed in the form,

$S(t)=f(\gamma) \int_{-\infty}^{\infty} H e^{-t / \theta} d(\ln \theta)$,

where $\mathrm{H}$ represents the relaxation spectra which is a function of relaxation time, $\theta$.

$f(\gamma)$, the non-linear factor, is a function of strain, $\gamma$, and the following empirical equation was obtained.

$f(\gamma)=a \ln [1+(\gamma / a)]$.

Here $a$ is a factor independent of $\gamma$. The value of $a$ appeared to be equal to unity for raw and oil-extended rubbers but smaller than unity in filler-loaded rubbers.

訂正 ت゙ム協 39，168，177，194刀報文について，沅植がありますので訂正致します。

\begin{tabular}{|c|c|c|c|}
\hline 頁 数 & 行 & 识 & 正 \\
\hline 171 & 右式(25) & $\mu_{M}$ & $\lambda_{M}$ \\
\hline 178 & 左: 1 & 2 近似法 & Ferrry-Williams ${ }^{12)} の$ 第 2 近似法 \\
\hline 181 & 有 $\uparrow 9$ & 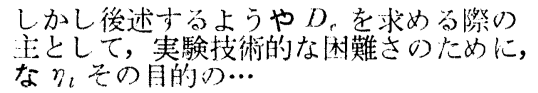 & 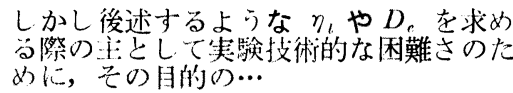 \\
\hline 183 & 㓙13站明 13 & よ执よび申 & 只执よびる \\
\hline 194 & $t_{1}: \uparrow 9$ & 著しいほどの原因 & 著しいなどり原因 \\
\hline 194 & t: i 3 & 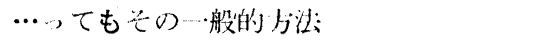 & …，てそい一般的力法 \\
\hline 196 & 表 $1 \# 15000$ & -7.50 & 7.50 \\
\hline 196 & 左芒个3 & 近似的関数係 & 近似的関数関係 \\
\hline 197 & 左: 2 & かつ分子量: & かつ高分子量 \\
\hline 197 & 左: 12 & $H_{\iota}$ 長緩和時間 & $H_{\imath}$ の表緩和時間 \\
\hline 197 & 枌†3 & $\eta_{l}$ の試料平均分子㼂 & $\eta_{t}$ が試料の平圴分子星 \\
\hline 198 & 左: 12 & 本閒 ${ }^{13)}$ には & 本間13) は \\
\hline 198 & 有文献10） & $34,184(1964)$ & $37, \quad 184(1964)$ \\
\hline
\end{tabular}

